\title{
SIKAP DAN PARTISIPASI MASYARAKAT DALAM MENYELESAIKAN PERMASALAHAN LINGKUNGAN HIDUP
}

\author{
Felisia Mega Sri Ayu ${ }^{1}$, YohanesIndra Christianto ${ }^{2}$, Anita Trisiana ${ }^{3}$ \\ ${ }^{1}$ Mahasiswa PPKnUniversitasSlametRiyadi \\ ${ }^{2}$ Mahasiswa PPKnUniversitasSlametRiyadi \\ ${ }^{3}$ Dosen PPKnUniversitasSlametRiyadi
}

Info Artikel
Masuk: 16 Juni 2020
Revisi: 27 Juli 2020
Diterima: 4 Agustus 2020
Terbit: 15 Agustus 2020
Keywords:
Attitude, Participation,
Environmental Problems.

Kata kunci:
Sikap, Partisipasi,
Permasalahan
Lingkungan Hidup.
P-ISSN : 2550-0171
E-ISSN : 2580-5819
DOI 10.33061

\begin{abstract}
Environmental issues must be given special attention for the environment has a close relationship with living beings and all of its contents. Preservation, supervision and coaching with the purpose of improving the harmony, sustainability, harmony and balance of the environment. Thus it has become a necessity and responsibility, openness attitude and community participation in resolving the problems of the environment so as to achieve prosperity and continuity of generations of present and future generations.
\end{abstract}

\begin{abstract}
Abstrak
Permasalahan lingkungan hidup haruslah mendapat perhatian khusus mengingat lingkungan hidup memiliki hubungan erat dengan makhluk hidup serta segala isinya. Upaya pelestarian, pengawasan serta pembinaan dengan tujuan meningkatkan keselarasan, kelestarian, keserasian dan keseimbangan lingkungan hidup. Maka dari itu sudah menjadi tanggung jawab serta perlunya, keterbukaan sikap dan partisipasi masyarakat dalam menyelesaikan permasalahan lingkungan hidup sehingga mencapai kesejahteraan dan kelangsungan generasi kini dan generasi yang akan datang.
\end{abstract}

\section{PENDAHULUAN}

Menjaga kelestarian alam yang dimana menjadi lingkungan hidup bagi makhluk hayati dan segala isinya yaitu tanah, udara, air, lautan menjadi kewajiban yang utama. Permasalahan lingkungan hidup menghambat program pembangunan dan menjadi permasalahan yang sangat sulit dihadapi baik oleh negara yang berkembang maupun negara yang maju.

Adanya perdebatan antar masyarakat dunia, disamping telah menimbulkan dampak keprihatinan atas pelestarian lingkungan, pada dasarnya sudah menjadi isu-isu di antara masyarakat di dunia dan menyimpulkan jika nantinya penggunaan kekayaan alam tanpa pengelolaan lingkungan hidup akan habis juga. Maka dari itu peningkatan pengelolaan 
lingkungan hidup perlu di laksanakan segera untuk kepentingan generasi ke generasi yang akan datang.

Oleh karena itu, pengelolaanan serta mempelajari aspek-aspek hukum lingkungan sangat diperlukan guna mencapai tujuan pembangunan yang selaras dengan program pembangunan berkelanjutan dengan prinsip kelestarian lingkungan karena pembangunan lingkungan hidup dan pembangunan ekonomi saling menunjang sebagai tolok ukur yang komprehensif yang perlu dipedomani sebagai usaha nyata meningkatkan kualitas lingkungan hidup.

\section{METODE PENELITIAN}

Metode yang digunakan merupakan metode deskriptif. pengertian dari metode deskriptif analitik menurut soegiono $(2009 ; 29)$ adalah: "metode Deskriptif adalah suatu metode yang berfungsi untuk mendeskripsikan atau sempel yang telah terkumpul sebagaimana adanya tanpa melakukan analisis dan membuat kesimpulan yang berlaku untuk umum, dengan demikian penelitian deskriptif analitik mengambil suatu permasalahan atau memusatkan perhatian terhadap suatu permasalahan sebagaimana adanya saat penelitian yang kemudian diolah dan dianalisis untuk diambil kesimpulanya". Disebut deskriptif dikarenakan bertujuan untuk memperoleh pemaparan yang obyektif mengenai masalah analisis terhadap permasalahan lingkungan hidup secara lebih mendalam.

\section{PEMBAHASAN}

\section{Partisipasi Masyarakat}

Partisipasi masyarakat dapat disebut sebagai perwujudan dari hak dan kewajiban warga negara yang diimplementasikan secara orientasi melalui eksistensi yang utuh untuk mendukung program pembangunan yang efektif dan efesien. Partisipasi masyarakat bertujuan untuk melibatkan masyarakat secara aktif dalam mewujudkan program pembangunan yang dijalankan oleh pemerintah.

Menurut Suryono (2001:124) dalam proses pembangunan masyarakat terlibat aktif dalam kegiatan dan memanfaatkan serta menikmati hasil dari pembangunan. 
Menurut pendapat Mubyarto (1997:35) "bahwa mendefinisikan partisipasi sebagai kesediaan untuk membantu keberhasilan setiap program sesuai dengan kemampuan setiap orang tanpa berarti mengorbankan kepentingan diri sendiri”.

Conyers (1991) "memberikan tiga alasan utama sangat pentingnya partisipasi masyarakat dalam pembangunan", yaitu:

1. Partisipasi masyarakat merupakan suatu alat guna memperoleh informasi mengenai kondisi, kebutuhan dan sikap masyarakat setempat, yang tanpa kehadirannya program pembangunan dan proyek akan gagal.

2. Masyarakat mempercayai program pembagunan jika dilibatkan dalam proses persiapan dan perencanaannya, karena masyarakat lebih mengetahui seluk beluk proyek dan merasa memiliki proyek tersebut.

3. Partisipasi merupakan hak demokrasi masyarakat dalam keterlibatannya di pembangunan.

Partisipai masyarakat menjadi hal yang sangat penting dalam sebuah tujuan pembangunan mengingat bahwa masyarakat tidak hanya menjadi obyek melainkan juga sebagai subyek dalam tujuan pembangunan tersebut. Indikator partisipasi masyarakat dapat dilihat dari:

1. Kontribusi Masyarakat yang meliputi:

Kontribusi Pemikiran, Kntribusi Dana, Kontribusi Tenaga, dan Kontribusi Sarana.

2. Pengorganisasian Masyarakat yang meliputi :

Model Pengorganisasian, Struktur Pengorganisasian, Unsur - Unsur Pengorganisasian, dan Fungsi Pengorganisasian.

3. Pemberdayaan Masyarakat yang meliputi:

Peran Masyarakat, Aksi Masyarakat, Motivasi Masyarakat, dan Tanggungjawab Masyarakat.

\section{Permasalahan lingkungan hidup}


Tanpa kita sadari,sikap dan partisipasi masyarakat dalam terkait permasalahan lingkungan hidup masih sangat rendahkarena masalah lingkungan hidup pada dasarnya timbul karena selain faktor alam juga pengaruh kebiasaan pola hidup masyarakat. Pertumbuhan dan pertambahan penduduk yang sangat cepat, persebaran yang tidak proposional, tidak adanya keseimbangan antar struktur penduduk mengakibatkan munculnya perkampungan kumuh akibat padat penduduk. Banyak dilihat letak-letak rumah penduduk tidak pada lokasi strategis perumahan sehingga mengakibatkan banyaknya lokasi kumuh yang tidak ramah lingkungan.

Penggunaan serta pengelolaan kekayaan alam yang kurang bijaksana karena dikejar target keuntungan yang besar, berbagai sumber alam diambil sebanyaknya tanpa memperthatikan generasi yang akan datang. Dampaknya terhadap kerusakan sangat besar. Tidak terkendalinya pemanfaatan ilmu pengetahuan teknologi maju. Seperti saat ini teknologi yang digunakan untuk mennyedot minyak dari perut bumi menggunakan teknologi canggih sehinngga manusia berlomba untuk menyedot minyak dalam jumlah jutaan dalam satu barel per hari. Demikian halnya sama dalam teknologi untuk proses penebangan hutan. Memang memanfaatkan teknologi sangat memudahkan segala aktifitas taetapi apabila penggunaan tidak bijak maka akan mengakibatkan kerugian.

Dampak yang sering timbul dari kemajuan dan perkembangan ekonomi adalah timbulnya industri yang begitu banyak,tidak jarang dapat menyebabkan kerusakan dan pencemaran terhadap lingkungan seperti pencemaran yang terjadi pada hulu sungai maupun pada muara sungai. berdampak pada mata pencaharian masyarakat sekitar dan merusak ekosistim di sekitar aliran sungai tersebut . Tidak jarang juga menimbulkan kejahatan pada kota besar karena sulitnya mencari pekerjaan. Benturan terhadap tata ruang juga mempengaruhi permasalahan lingkungan hidup. Kawasan yang semula di gunakan untuk tempat reboisasi di jadikan sebagai kawasan industri dan kawasan yang semula di seharuskan menjadi taman nasional menjadi tempat yang penuh bangunan oleh karena itu perlu adanya solusi yang sekiranya dapat menumbuhkan sikap dan partisipasi masyarakat dalam mengatasi permasalahan lingkungan hidup.

Solusi sikap partisipasi masyarakat dalam menyelesaikan permasalahan lingkungan hidup 
Solusi yang paling tepat untuk menyelesaikan permasalahan lingkungan hidup dapat dilakukan dengan banyak cara. Misalnya dengan mengajak masyararakat untuk berpartisipasi menjamin pelestarian lingkungan hidup. Masyarakat diajak mengutamakan pengelolaan sumber daya yang dapat di perbarui. Selain itu masyarakat juga diajak melakukan pengamatan terhadap sumber daya alam yang sudah langka agar mampu melestarikan dan merawat untuk mencegah punahnya sumber daya alam tersebut. Selain itu pihak pemerintah ataupun lembaga yang bergerak dalam bidang pelestarian lingkungan melakukan pengembangan rencana penggunaan lahan serta tata ruang. Dan untuk menangani kerusakan sumber daya alam yang terjadi dapat dilakukan dengan cara merehabilitasi kerusakan sumber daya alam yang terjadi seperti kerusakam tanah,air, dan hutan serta memberikan nilai kelangkaan terhadap sumber daya alam yang langka,agar mendapat prioritas utama dan penyelamatan serta perlindungan. Seluruh aspek masyarakat harus sadar serta menumbuhkan sikap peduli dan mau untuk memelihara sumber daya alam guna menopang pembangunan secara berkelanjutan demi kesejahteraan bersama.

\section{KESIMPULAN}

Program pembangunan berkelanjutan pada suatu wilayah tidak terlepas dari lingkungan hidup. Pengelolaan lingkungan hidup sangat penting baik untuk generasi ini maupun generasi yang akan datang serta untuk keseimbangan ekosistem alam. Akan tetapi apabila membahas lingkungan hidup tidak terlepas dari masalah - masalah kerusakan sumber daya alam yang sangat marak terjadi. Ini terjadi tidak hanya karena faktor alam akan tetapi juga faktor kebiasaan masyarakat dalam mengelolan lingkungan hidup. Dalam mengatasi permasalahan lingkungan hidup dapat dilakukan melalui kerjasama antara pemerintahan, lembaga sosial peduli lingkungan, tokoh - tokoh masyarakat serta peran masyarakat pula untuk sadar dan mau saling menjaga sumber daya alam yan ada serta melestarikan lingkungan hidup.

\section{Saran}

Mari kita lestarikan lingkungan hidup serta menjaga kekayaan alam yang ada untuk kepentingan generasi yang akan datang dan program pembangunan yang berkelanjutan. 


\section{DAFTAR PUSTAKA}

Salindeho, J. 1989. Undang - Undang Gangguan Dan Masalah Lingkungan. Jakarta: Sinar Grafika.

Sunarso, Siswanto. 2005. Hukum Pidana Lingkungan Hidup Dan Strategi Penyelesaian Sengketa. Jakarta: Rineka Cipta.

Silalahi, Daud. 1992. Hukum Lingkungan Dalam Sistem Penegakan Hukum Lingkungan Indonesia. Bandung: Alumni.

Supriadi, 2008. Hukum Lingkungan Di Indonesia. Jakarta: Sinar Grafika.

Mustaruddina., Wiyonoa, E.S., Khotibb., Asnilc., Bahrid S. (2018). Pola Pencemaran Lokasi Penangkapan Dan Ikan Hasil Tangkapan Akibat Berkembangnya Aktivitas Ekonomi Di Sekitar Danau Maninjau. Jurnal Pengelolaan Sumberdaya Alam dan Lingkungan, 8, 134-142.

Suharko. (2014). Pencegahan Bencana Lingkungan Hidup Melalui Pendidikan Lingkungan. Jurnal Manusia Dan Lingkungan, 21, 254-260.

Haryadi., \&Setiawan, B. (2002). Penyusunan Indikator - Indikator Keberlanjutan Kota Di Indonesia. Jurnal manusia dan Lingkungan, 9, I5-125.

McMichael., J.A., Woodruff., R.E., \& Hales., S. (2006). Climate Change And Human Health: Present And Future Risks. 367, 859-870.

Ostrom, R. (2010). Polycentric Systems For Coping With Collective Action And Global Enviromental Change. 20, 550-557.

Vitousek., P. M., D’Antonio., C.M., Loope., L.L., \& Westbrooks., R. (1996). Biological Invasions as Global Environmental Change. 218-228. 